Research article

\title{
Mapping wildfire vulnerability in Mediterranean Europe. Testing a stepwise approach for operational purposes
}

\author{
Sandra Oliveira ${ }^{\mathrm{a},{ }^{*}}$, Fernando Félix ${ }^{\mathrm{b}}$, Adélia Nunes ${ }^{\mathrm{c}}$, Luciano Lourenço ${ }^{\mathrm{c}}$, \\ Giovanni Laneve ${ }^{\mathrm{d}}$, Ana Sebastián-López ${ }^{\mathrm{e}}$ \\ a Institute of Geography and Spatial Planning, Universidade de Lisboa (University of Lisbon), Edificio IGOT, Rua Branca Edmée Marques, Cidade \\ Universitária, 1600-276, Lisbon, Portugal \\ ${ }^{\mathrm{b}}$ Núcleo de Investigação Científica de Incêndios Florestais, Universidade de Coimbra (University of Coimbra), Aeródromo da Lousã, Chã do Freixo, 3200-395, \\ Lousã, Portugal \\ ${ }^{\mathrm{c}}$ Departamento de Geografia e Turismo, CEGOT - Centro de Estudos de Geografia e Ordenamento do Território, Universidade de Coimbra (University of \\ Coimbra), Faculdade de Letras, Colégio de S. Jerónimo, 3004-530, Coimbra, Portugal \\ d University of Rome 'La Sapienza', Scuola di Ingegneria Aerospaziale, Via Salaria 851, 00138, Rome, Italy \\ e GMV UK, Harwell Innovation Centre, 173 Curie Avenue, Harwell, Oxford, OX11 0QG, United Kingdom
}

\section{A R T I C L E I N F O}

Article history:

Received 12 October 2016

Received in revised form

16 June 2017

Accepted 6 October 2017

Available online 20 October 2017

\section{Keywords:}

Wildfire vulnerability

Exposure

Stepwise procedure

Mediterranean Europe

Local users

\begin{abstract}
A B S T R A C T
Vulnerability assessment is a vital component of wildfire management. This research focused on the development of a framework to measure and map vulnerability levels in several areas within Mediterranean Europe, where wildfires are a major concern. The framework followed a stepwise approach to evaluate its main components, expressed by exposure, sensitivity and coping capacity. Data on population density, fuel types, protected areas location, roads infrastructure and surveillance activities, among others, were integrated to create composite indices, representing each component and articulated in multiple dimensions. Maps were created for several test areas, in northwest Portugal, southwest Sardinia in Italy and northeast Corsica in France, with the contribution of local participants from civil protection institutions and forest services. Results showed the influence of fuel sensitivity levels, population distribution and protected areas coverage for the overall vulnerability classes. Reasonable levels of accuracy were found on the maps provided through the validation procedure, with an overall match above $72 \%$ for the several sites.

The systematic and flexible approach applied allowed for adjustments to local circumstances with regards to data availability and fire management procedures, without compromising its consistency and with substantial operational capabilities. The results obtained and the positive feedback of end-users encourage its further application, as a means to improve wildfire management strategies at multiple levels with the latest scientific outputs.
\end{abstract}

() 2017 Elsevier Ltd. All rights reserved.

\section{Introduction}

Wildland fires are recurrent events in southern Europe and a major cause of land degradation in this region (Pausas et al., 2008; Rodrigues et al., 2013; San-Miguel-Ayanz et al., 2013; Turco et al., 2016). Particular physical and human circumstances contribute to this high incidence of wildfires. In fact, the Mediterranean climatic conditions, with the temporal coincidence of the driest with the

\footnotetext{
* Corresponding author.

E-mail addresses: sisoliveira@gmail.com, sandra.oliveira1@campus.ul.pt (S. Oliveira)
}

hottest season, and the predominance of Mediterranean-type vegetation, result in fire-prone landscapes (Ganteaume et al., 2013; Moreira et al., 2011; Roberts et al., 2001; Urbieta et al., 2015). Moreover, the coexistence of urban settlements, infrastructure networks and vegetated areas in a complex and intimately interconnected patchwork increase fire hazard. This is exacerbated by the recent changes in demographic patterns and land use, combined with the diminished control on traditional practices involving fire as an instrument for land management (Badia et al., 2011; Gomes, 2006; Lampin-Maillet et al., 2011; Moreira et al., 2011; Nunes et al., 2016; Pausas et al., 2008; Ruiz-Mirazo et al., 2012; San-Miguel-Ayanz et al., 2012a). Fire activity in this region is 
also likely to intensify due to climate change, aggravating its impacts on the environment and society (Amatulli et al., 2009; Amraoui et al., 2013; Carvalho et al., 2011; Giannakopoulos et al., 2009; Kovats et al., 2014; Moreno, 2009; Moriondo et al., 2006).

In this context, evaluating the impacts of wildfire occurrence and developing approaches to prevent potential damages are critical for fire management. Vulnerability assessment provides particular tools to analyse the potential for loss and has received growing attention at the international level (Cutter, 2015; UNISDR, 2015). Previous efforts have been made to define logical and consistent vulnerability assessment approaches; some studies focused specifically on the ecological dimension of wildfires (Aretano et al., 2015; Duguy et al., 2012; Ibarra et al., 2007), whereas others were centred around socio-economic aspects (Rodríguez et al., 2013; Román et al., 2013). Holistic frameworks have also been tested, attempting to integrate the wide range of potential impacts and interactions of wildfires (Birkmann et al., 2013; Chuvieco et al., 2014; Ortega et al., 2012; Tedim et al., 2013). These studies presented valuable alternatives to implement systematic approaches for evaluating vulnerability, however some challenges persist. The lack of data for all the variables integrated, in a suitable scale and format, and their consistent aggregation in meaningful indicators, are relevant issues (Birkmann et al., 2013; Chuvieco et al., 2014; Kuhlicke et al., 2011). Other main challenge regards the need to transfer the scientific knowledge resulting from these complex approaches into technical and operational procedures, required in other sectors linked to wildfire management.

\subsection{Background and objectives}

The research here presented tried to respond to these challenges. The main purpose was to develop a structured approach for vulnerability assessment of wildfires, based on recent scientific outcomes and implemented for operational purposes, applicable within the geographical context of Mediterranean Europe.

This study was integrated into the framework of an European research project (PREFER - Space-based Information Support for Prevention and Recovery of Forest Fires Emergency in the Mediterranean area, G. A. nr. 312931), dedicated to the development of a service infrastructure for the provision of EO-based (Earth Observation) cartographic products related to fire management activities in the Southern European countries most affected by wildfires, namely France, Greece, Italy, Portugal and Spain (EC, 2015; Turco et al., 2016). Vulnerability assessment was part of the range of services provided, together with fuel mapping, daily and seasonal hazard maps and burned areas mapping at very high-resolution, among others. Institutions working on wildfire management of the participating countries, specifically Civil Protection Departments, Forest Services, Fire Brigades and regional Environmental Agencies, were involved as stakeholders during the several phases of the project, to ensure the operational application of the outputs developed (Laneve et al., 2014; Oliveira et al., 2017a).

Following the outcomes of previous studies and the specific goals of the PREFER project, this research was steered by three main objectives:

i) the identification of common components and variables in multi-hazard vulnerability assessments that are suitable for wildland fire research;

ii) the delivery of cartographic products that represent wildfire vulnerability and its multiple spatial interactions;

iii) the development of products adjusted to the needs of endusers and with practical implementation, to contribute to decision-making processes from an operational perspective.
The methodological procedure implemented and the results obtained for different test sites are presented. The advantages and limitations of this approach, the main challenges for its operational use and the implications for further application in other areas, are discussed.

\section{Materials and methods}

\subsection{Study area}

The vulnerability framework was designed to be implemented in any area within the 5 Southern European countries most affected by wildfires (Fig. 1). Within this region, several sites were selected to test the framework developed, based on the following criteria: i) the characteristics of the area with regards to fire occurrence; ii) the availability of suitable data; iii) the possibility of obtaining feedback from potential users, stakeholders of the project, in relation to the outputs provided with the framework. The sites selected were the Minho region, in northwest Portugal, and the southwest of Sardinia, in Italy. Additionally, to evaluate the replicability of this framework, the procedure was applied to another site in Northeast Corsica, in France (Fig. 1).

Minho region, Portugal (Fig. 1, 1). Minho is one of the most fireaffected regions in Portugal, with over 3.000 fire events and about 17.000 ha of burned area annually in recent years. This region occupies $4.700 \mathrm{~km}^{2}$ and is composed of 24 municipalities. The eastern side of the region is occupied by the protected area of PenedaGerês, recognized at the international level.

SW Sardinia (Fig. 1, 2). This test site was located in the Southwestern part of Sardinia island, covering about $3000 \mathrm{~km}^{2}$. It comprised the whole province of Carbonia-Iglesias and part of the Cagliari and Medio-Campidano provinces. Forest fires represent the main source of risk for this area. It hosts the protected area of Monte Arcosu Forest, one of the biggest holm oak forests of the Mediterranean region.

NE Corsica (Fig. 1, 3) - The island of Corsica occupies an area of $8.680 \mathrm{~km}^{2}$ and is composed of 2 departments: Corse-du-Sud (SW) and Haute-Corse (NE), the test site being located in the latter. On average, more than 500 fires burn over 1000 ha per year throughout the region. The inner part of the island, predominantly rural and intersecting both regions, is classified as a Regional Natural Park.

\subsection{The wildfire vulnerability framework}

The methodological approach was designed to accommodate specific adjustments required for an operational application, associated with fire management procedures already in place in the participating countries. This was enabled by integrating the feedback of stakeholders and potential users in the development of the service infrastructure from the beginning, and by delivering outputs which complied with a harmonized set of technical requirements defined in view of users' needs and suitable scientific options based on recent research.

The vulnerability framework developed followed a comprehensive approach and inherited its main structure from recent scientific studies (e.g. Birkmann et al., 2013; Chuvieco et al., 2014, 2010; Turner et al., 2003). It analyses the assets, or values-at-risk, that can be affected by a wildfire, integrating variables that reflect different dimensions: social (population), physical (buildings and road infrastructure) and environmental (fuels/vegetation and protected areas). In addition, institutional resources which affect the coping capacity of communities were included, such as surveillance and fuel management activities.

The vulnerability assessment framework integrated three main 


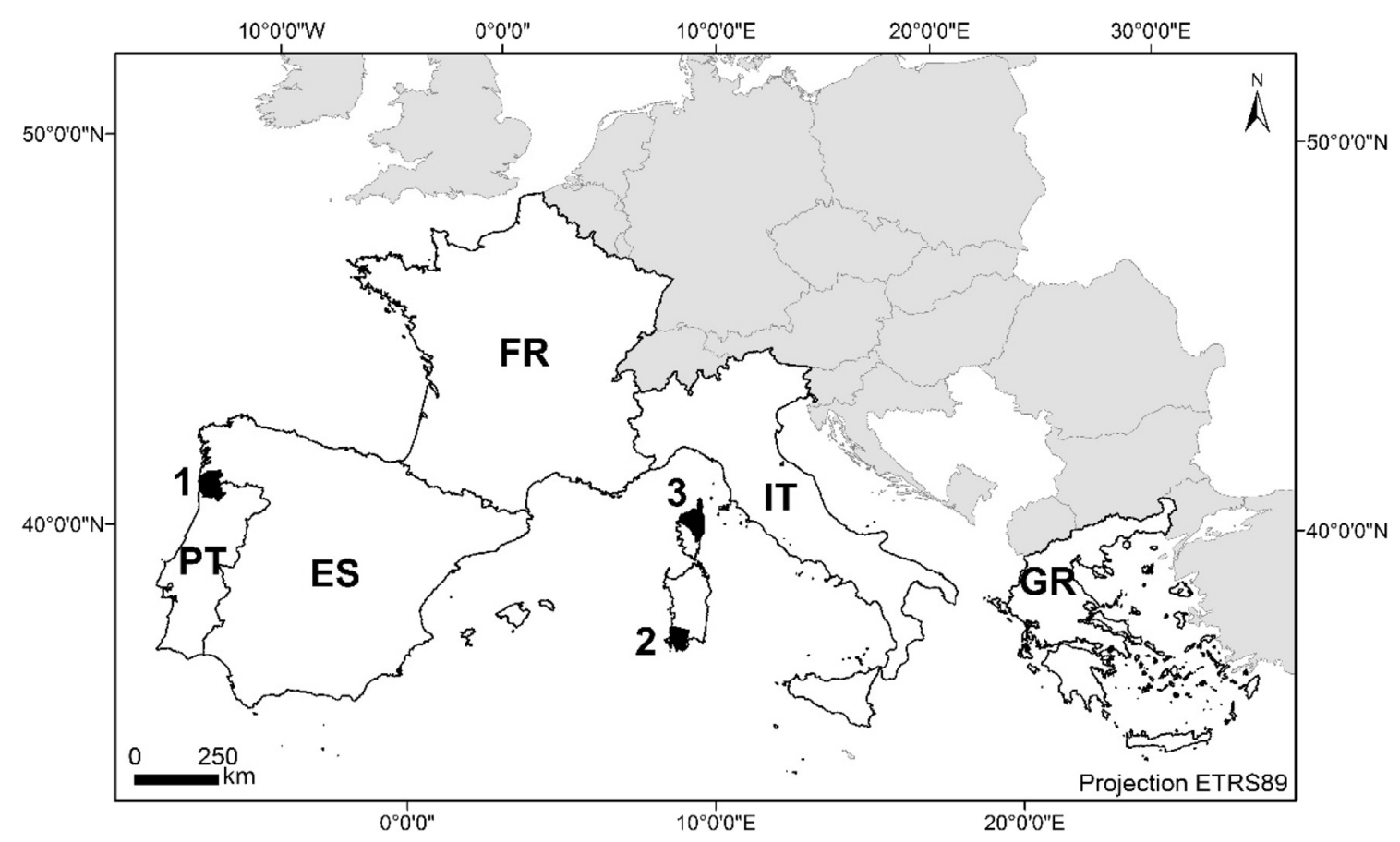

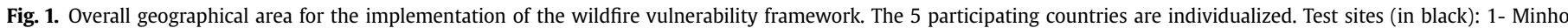
region, Portugal; 2- SW Sardinia, Italy; 3- NE Corsica, France.

$$
\text { components: }
$$

a) Exposure, representing the presence of assets (people, property, ecosystems) in areas where wildfires may occur (Aubrecht et al., 2013; Gallina et al., 2016; Salis et al., 2015, 2013; UNISDR, 2009);

b) Sensitivity, representing the degree to which these assets can be affected by a wildfire, linked to their predisposition to suffer certain type and magnitude of losses (Aretano et al., 2015; Birkmann et al., 2013; Cutter, 2011; Murthy et al., 2015);

c) Coping capacity, related to the measures applied to anticipate potential effects or to respond in case a fire occurs (Birkmann et al., 2013; Tedim et al., 2013), based on institutional practices within the several countries.

Each of these components was converted into a composite index that could be provided separately. In view of different conceptual approaches, exposure and coping capacity could be considered separately from vulnerability (e.g., Ciurean et al., 2013; Costa and Kropp, 2013; Oppenheimer et al., 2014; UNISDR, 2009), but since they constitute crucial steps for the assessment of potential losses they were integrated in the overall framework.

The final vulnerability index combines the three intermediate components and provides a relative measure of the maximum potential for loss, in case a fire occurs in a certain area, considering the characteristics of the assets found in that area.

\subsubsection{Processing chain}

The framework was implemented with a stepwise approach, with each step resulting in a specific output (Fig. 2). The processing chain was developed using scripting techniques with python ${ }^{\circledR}$ software with automated routines, to support its systematic application to different areas and enable frequent updates, by season or year. To ensure the consistency of the procedure throughout the several steps, a set of technical rules was defined (Table 1), to simplify its interpretation and enable further implementation.

\subsection{Data collection and analysis}

The analysis of each component of vulnerability included a set of variables representing the exposed assets and coping measures, within specific dimensions (social, environmental, physical/infrastructures or institutional, Fig. 2). The selection of the variables was based on extensive literature review and on the possibility to obtain the required data in a suitable format, while keeping the operational perspective. Different sources were screened and local or regional datasets were used whenever possible, taking into account their resolution, scale and assembly time. When local data were not available, European or worldwide datasets deemed appropriate were used instead. A brief description of the variables is presented below and further details are available as supplementary material (Table 2).

\subsection{Variable weighting and aggregation}

The weighting of the variables was obtained from previous studies outputs, a preliminary analysis of the data available and through stakeholder engagement. The weighting represents a relative measure of the contribution of each variable to the potential for loss derived from wildfires. Based on the procedures implemented in their institutions and their experience, stakeholders defined social losses as the dominant concern, mainly the human lives potentially lost, which are the top priority of fire management strategies in all participating countries. Fuel types are directly related to fire ignition and behavior and they have a strong influence on the potential damage fire can cause. Therefore, population and fuels were evaluated as the most relevant values-at-risk and received a higher weighting within the model.

For retrieving sensitivity values of the elements exposed, and due to data constraints, only two dimensions were covered: human and environmental, with fuel and population sensitivity receiving higher and equivalent weights, following the stakeholder consultation. 


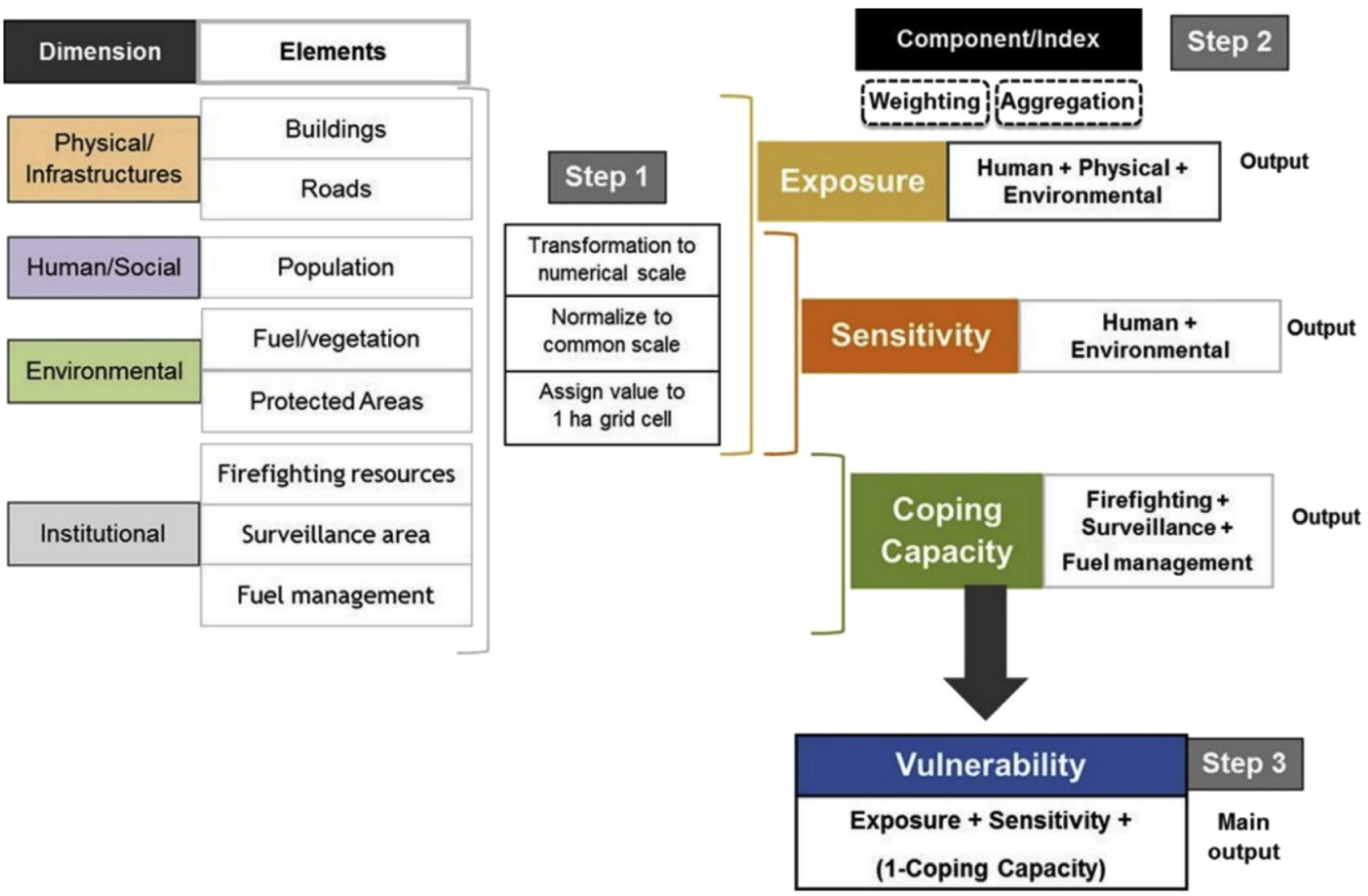

Fig. 2. Stepwise approach of wildfire vulnerability assessment, with the elements (assets and resources), dimensions and components integrated.

Table 1

Processing rules defined to implement the framework, according to the specific purposes of the research.

\begin{tabular}{|c|c|}
\hline Purpose & Processing rules \\
\hline $\begin{array}{l}\text { Obtain the best possible compromise between the spatial resolution of data } \\
\text { obtained from different sources (for example, remote sensing data at very } \\
\text { high resolution and statistical data at municipality level) }\end{array}$ & $\begin{array}{l}\text { Spatial resolution of the maps was defined as } 1 \text { ha. A base grid at } 100 \mathrm{~m} \text { was } \\
\text { created for the overall study area based on the European grid available from the } \\
\text { EEA at } 1 \mathrm{~km} \text { using GIS tools (http://www.eea.europa.eu/data-and-maps/data/ } \\
\text { eea-reference-grids-2) }\end{array}$ \\
\hline Ensure the consistent aggregation of data from different sources and formats & $\begin{array}{l}\text { All variables were, first, transformed to a numerical scale, as proportions } \\
\text { (protected areas coverage), densities (population) or ratios (for example } \mathrm{nr} \text {. } \\
\text { firefighters in relation to fuels coverage) } \\
\text { All variables were normalized to a common scale ( } 0-1) \text { within each test site, } \\
\text { with the formula: } \\
\text { norm (var } \mathbf{0}-\mathbf{1})=\mathbf{v a r}(\mathbf{v a l u e}) \text { - } \min (\mathbf{v a r}) / \mathbf{m a x}(\mathbf{v a r}) \text {-min(var) } \\
\text { with norm(var } 0-1 \text { ) being the resulting normalized value in the scale } 0 \text { to } 1 \text {; var } \\
\text { (value), the value of the variable obtained for the grid cell; min (var), the minimum } \\
\text { value of that variable in the test site; the max (var), the maximum value of that } \\
\text { variable obtained in the test site. }\end{array}$ \\
\hline $\begin{array}{l}\text { Provide cartographic products scientifically sound and technically robust, with } \\
\text { the systematic application of the stepwise processing chain. }\end{array}$ & $\begin{array}{l}\text { Each component (exposure, sensitivity and coping capacity) was, first, analyzed } \\
\text { individually, creating composite indices from the variables included. The three } \\
\text { indices were subsequently aggregated to compute the overall vulnerability level } \\
\text { Outputs were obtained at each step of the processing chain and can be updated } \\
\text { frequently, These intermediate products are useful for different stages of fire } \\
\text { management and for different users }\end{array}$ \\
\hline Develop decision-making tools able to be applied at the operational level. & $\begin{array}{l}\text { Create cartographic products at the several steps, updated according to users' } \\
\text { needs and ensuring the possibility to integrate more or better data when } \\
\text { available } \\
\text { All the variables were spatialized based on the reference grid. Variables and } \\
\text { intermediate indices could be represented cartographically and aggregated at } \\
\text { different spatial scales. }\end{array}$ \\
\hline
\end{tabular}

The coping capacity index covered the institutional dimension and, based on the practices of the different users and institutions involved, each variable received an equal weight. Unlike exposure and sensitivity, where higher values represent areas that require more urgent attention, in coping capacity higher values represent areas where more coping measures have been applied. To maintain the consistency in the interpretation of the indexes and maps, the coping capacity component was transformed in a reverse scale 
Table 2

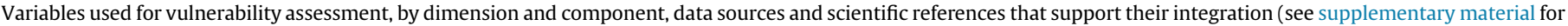
further details).

\begin{tabular}{|c|c|c|c|c|c|c|}
\hline Dimension & Code & Value-at-risk/Resource & Component & Variable & Sources & References \\
\hline \multirow[t]{2}{*}{ Human/Social } & \multirow[t]{2}{*}{ A } & \multirow[t]{2}{*}{ Population } & Exposure & $\begin{array}{l}\text { Population density (nr. } \\
\text { people/ha) }\end{array}$ & $\begin{array}{l}\text { Census } 2011(\mathrm{PT}) \\
\text { mapas.ine.pt }\end{array}$ & \multirow{2}{*}{$\begin{array}{l}\text { Aubrecht et al., 2013; Birkmann et al., 2013; } \\
\text { Cutter, 2011; Cutter et al., 2003; Gaither et al., } \\
\text { 2011; Kuhlicke et al., 2011; Tapsell et al., 2010; } \\
\text { Taubenböck et al., } 2008\end{array}$} \\
\hline & & & Sensitivity & $\%$ people $>64$ years old & $\begin{array}{l}\text { Census } 2011 \text { (IT) } \\
\text { www.istat.it }\end{array}$ & \\
\hline \multirow[t]{4}{*}{ Environment } & \multirow[t]{2}{*}{ B } & \multirow[t]{2}{*}{ Vegetation/fuel types } & Exposure & \multirow{2}{*}{$\begin{array}{l}\% \text { area covered by fuels } \\
\text { or burnable land cover } \\
\text { Weighting of fuel or } \\
\text { land cover types } \\
\text { according to fire } \\
\text { proneness and recover } \\
\text { ability }\end{array}$} & $\begin{array}{l}\text { Fuel map from PREFER } \\
\text { project }\end{array}$ & \multirow{2}{*}{$\begin{array}{l}\text { Barros and Pereira, 2014; Carmo et al., 2011; } \\
\text { Chas-Amil et al., 2013; Chuvieco et al., 2010; } \\
\text { Ganteaume et al., 2013; Laneve et al., 2014; } \\
\text { Moreira et al., 2011, 2001; Oliveira et al., } 2014\end{array}$} \\
\hline & & & Sensitivity & & & \\
\hline & \multirow[t]{2}{*}{$\mathrm{C}$} & \multirow[t]{2}{*}{ Protected natural areas } & Exposure & $\begin{array}{l}\% \text { area covered by any } \\
\text { type of protected areas }\end{array}$ & $\begin{array}{l}\text { Forest services (PT) } \\
\text { icnf.pt } \\
\text { Sardinia geodatabase } \\
\text { (IT) } \\
\text { sardegnageoportale.it }\end{array}$ & \multirow[t]{2}{*}{$\begin{array}{l}\text { Aretano et al., 2015; Chuvieco et al., 2014; } \\
\text { Dudley and Stolton, 2008; Geldmann et al., } \\
\text { 2013; Naughton-Treves et al., 2005; Salis et al., } \\
2013\end{array}$} \\
\hline & & & Sensitivity & $\begin{array}{l}\text { Weighting of protected } \\
\text { areas according to } \\
\text { levels of protection and } \\
\text { IUCN category }\end{array}$ & $\begin{array}{l}\text { World Database on } \\
\text { Protected Areas WDPA } \\
\text { protectedplanet.net }\end{array}$ & \\
\hline \multirow[t]{2}{*}{ Infrastructure } & $\mathrm{D}$ & Buildings & Exposure & \multirow{2}{*}{$\begin{array}{l}\text { Building density } \\
\text { (nr. buildings/ha) } \\
\text { Road density } \\
\text { (length/ha) }\end{array}$} & $\begin{array}{l}\text { Census } 2011(\mathrm{PT}) \\
\text { mapas.ine.pt }\end{array}$ & \multirow{2}{*}{$\begin{array}{l}\text { Birkmann et al., 2013; Bowman et al., 2011; } \\
\text { Chuvieco et al., 2014 } \\
\text { Chas-Amil et al., 2013; Darques, 2015; Galiana- } \\
\text { Martín and Karlsson, 2012; Ganteaume et al., } \\
\text { 2013; Lampin-Maillet et al., 2011; } \\
\text { Ortega et al., 2012; Tedim et al., } 2013\end{array}$} \\
\hline & $\mathrm{E}$ & Roads & Exposure & & $\begin{array}{l}\text { Sardinia geodatabase } \\
\text { (IT) } \\
\text { sardegnageoportale.it }\end{array}$ & \\
\hline \multirow[t]{3}{*}{ Institutional } & $\mathrm{F}$ & Nr. firefighters & Coping Capacity & $\begin{array}{l}\text { Ratio of firefighters in } \\
\text { relation to exposed } \\
\text { fuels or land cover area }\end{array}$ & $\begin{array}{l}\text { National or Regional } \\
\text { Civil Protection } \\
\text { Services }\end{array}$ & Moreira et al., 2011 \\
\hline & G & Surveillance areas & Coping Capacity & $\begin{array}{l}\text { Number of surveillance } \\
\text { towers/paths with } \\
\text { visibility over the area }\end{array}$ & $\begin{array}{l}\text { National or Regional } \\
\text { Forest Services }\end{array}$ & $\begin{array}{l}\text { Raftoyannis et al., } 2014 \\
\text { Rego, } 2004\end{array}$ \\
\hline & $\mathrm{H}$ & Fuel management & Coping Capacity & $\begin{array}{l}\% \text { of area subject to fuel } \\
\text { reduction in relation to } \\
\text { exposed fuels area }\end{array}$ & $\begin{array}{l}\text { National or Regional } \\
\text { Forest Services }\end{array}$ & $\begin{array}{l}\text { Corona et al., 2015; Fernandes, 2013; Moreira } \\
\text { et al., } 2011\end{array}$ \\
\hline
\end{tabular}

(Table 3).

The aggregation of the variables was done with an additive-type model, to differentiate the effects of the individual variables in the modelling approach and to streamline the interpretation of the outputs, one of the requirements for their operational application.

The vulnerability index resulted from the combination of the three intermediate indices, based on the relative importance of each one for the overall vulnerability levels. Exposure was considered the key component and received a higher weighting, an option justified by the relevance of exposure analysis in wildfire studies, which can be assessed separately (Ager et al., 2014; Alcasena et al., 2015; Salis et al., 2015, 2013, Thompson et al., 2015, 2013), and its relationship with the other components; sensitivity to damages of a certain asset and the coping capacity of the area are only calculated if exposure exists.

\footnotetext{
Vulnerability $=\left(\right.$ Exposure $\left.^{*} 0.5\right)+\left(\right.$ Sensitivity $\left.{ }^{*} 0.3\right)+((1-$ Coping (apacity)*0.2)
}

The final vulnerability map expresses the maximum potential for loss, combined for all the assets present in an area. The relative values obtained (scale $0-1$ ) for the several components and the final vulnerability map were divided in 5 classes, in agreement with current operational tools within civil protection, fire brigades and forest services in the countries involved: class 1 (low, $0-0.2$ ); class 2 (moderate, $0.2-0.4$ ); class 3 (high, $0.4-0.6$ ); class 4 (very high, $0.6-0.8$ ); class 5 (maximum, $0.8-1$ ).

\subsection{Validation}

The validation procedure was guided by two main objectives:

Table 3

Weighting of variables (normalized to scale $0-1$ ) and calculation of each component of vulnerability.

\begin{tabular}{|c|c|c|c|c|}
\hline Component & Dimension & Variable & Weight & Calculation \\
\hline \multirow[t]{5}{*}{ Exposure } & Social & population density & 0.3 & Exposure $=\left[\left(\right.\right.$ population density $\left.{ }^{*} 0.3\right]+($ fuel \\
\hline & \multirow[t]{2}{*}{ Environmental } & fuel coverage & 0.3 & $\left.{ }^{*} 0.3\right)+\left(\right.$ protected areas $\left.{ }^{*} 0.2\right)+\left[\left(\right.\right.$ buildings ${ }^{*} 0.5+$ roads $\left.* 0.5\right)$ \\
\hline & & protected areas coverage & 0.2 & $* 0.2]$ \\
\hline & \multirow[t]{2}{*}{ Physical } & building density & 0.1 & \\
\hline & & roads density & 0.1 & \\
\hline \multirow[t]{3}{*}{ Sensitivity } & Social & population $>64$ years & 0.4 & \multirow{3}{*}{$\begin{array}{l}\text { Sensitivity }=(\text { Population*0.4 })+(\text { fuel } * 0.4)+(\text { protected } \\
\text { areas } 0.2)\end{array}$} \\
\hline & \multirow[t]{2}{*}{ Environmental } & fuel sensitivity level & 0.4 & \\
\hline & & protected areas sensitivity & 0.2 & \\
\hline \multirow[t]{3}{*}{ Coping capacity } & \multirow[t]{3}{*}{ Institutional } & firefighters/fuels & 0.33 & \multirow{3}{*}{$\begin{array}{l}\text { Coping capacity }=1-[(\text { firefighters* } 1 / \\
3)+\left(\text { fuel_management*1/3) }+\left(\text { surveillance }^{*} 1 / 3\right)\right]\end{array}$} \\
\hline & & fuel management area/fuels & 0.33 & \\
\hline & & visibility (surveillance/fuels) & 0.33 & \\
\hline
\end{tabular}




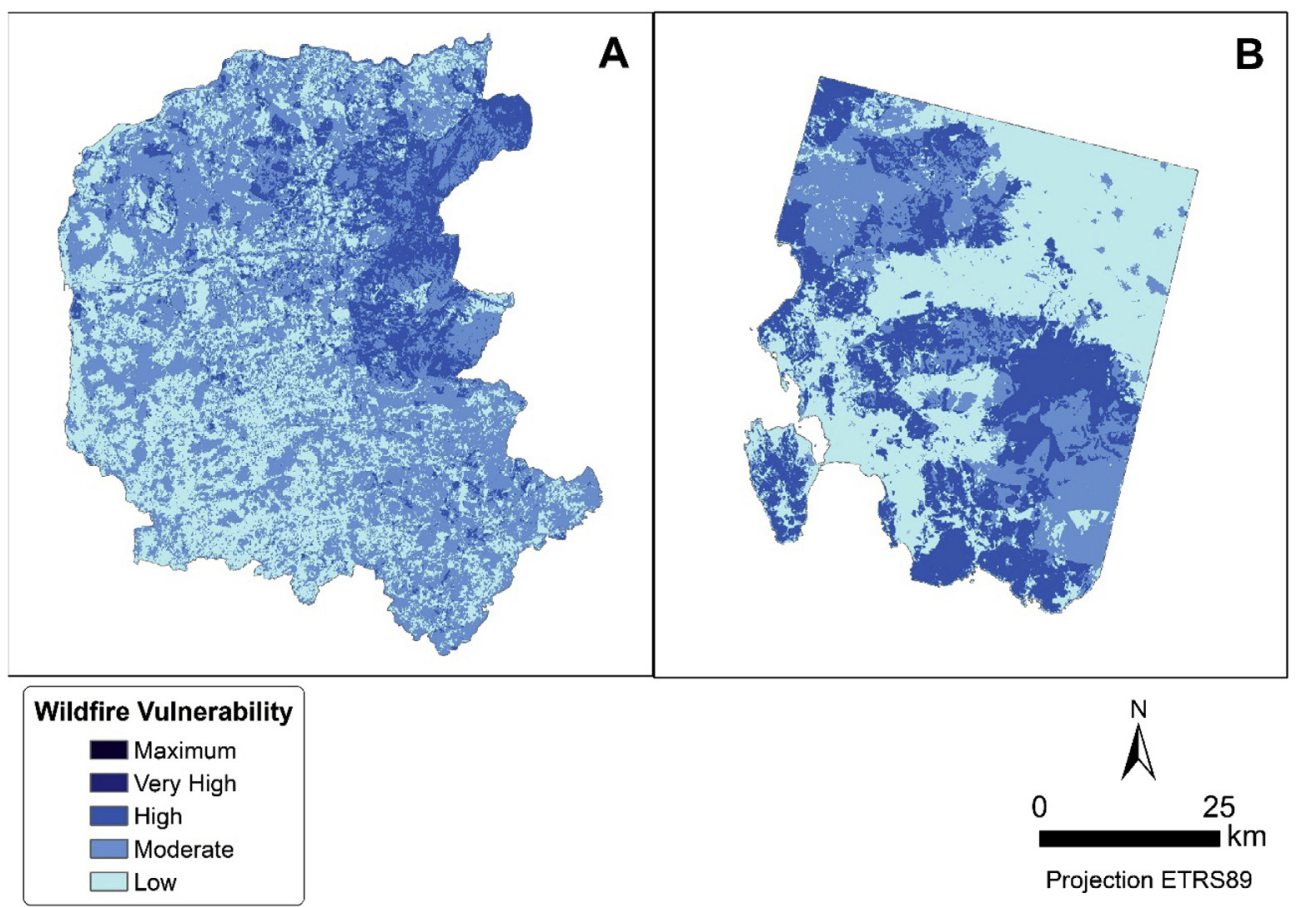

Fig. 3. Wildfire vulnerability maps for the test sites of Minho, Portugal (A) and SW Sardinia, Italy (B).

i) To verify the quality and reliability of the information provided by the indexes and maps created;

ii) To test the consistency and replication of the assessment procedure developed and the possibility of application in other areas.

For the first objective, the classes of vulnerability and its components, attributed by the model, were evaluated against independent data through visual interpretation. Firstly, a sample of $1 \%$ of the grid cells from the test sites of Portugal and Italy was selected. Stratified random sampling was applied based on the distribution of each class within the test sites. Satellite imagery at $1 \mathrm{~m}$ resolution obtained from DigitalGlobe through $\operatorname{ArcGIS}^{\circledR}$ was used to visually compare the density or coverage of the visible assets with the classes assigned by the model. This procedure was carried out essentially for the exposure maps, the only component that could be directly validated with this procedure.

Regarding the second objective, the replicability and timely application of the processing chain was evaluated by applying the procedure to a different area and calculating the resources required to complete each step, to ensure the delivery of consistent and updated products in the shortest possible time to potential endusers. Indices and maps regarding exposure and sensitivity parameters were computed for the region of Haute-Corse, in France, with data provided by local users, who also evaluated the outputs. Further details on the validation procedure can be found as supplementary material.

\section{Results and discussion}

\subsection{Wildfire vulnerability levels and intermediate indices}

\subsubsection{Minho region, NW Portugal}

Moderate wildfire vulnerability (class 2) predominated in Portugal's test site (Fig. 1, site 1), covering nearly $60 \%$ of the total area. High vulnerability levels (class 3 ) were found in $27.6 \%$ of the area and low vulnerability (class 1 ) was found in $12.5 \%$ of the test site.
The very high class was barely present and the maximum class was not assigned. Wildfire vulnerability levels were higher in the northeastern part (Fig. 3), partly reflecting the presence of the protected area of Peneda-Gerês, which occupies about $20 \%$ of the region. Despite the lower weighting, the importance of protected areas for vulnerability level within this framework is visible, based on scientific evidence that emphasizes the positive outcomes provided by protected areas regarding, for example, habitat and species conservation and ecosystems services (Geldmann et al., 2013), the support to local livelihoods and national development (Naughton-Treves et al., 2005) and the economic value associated with recreation and social benefits (Ninan and Inoue, 2013), including in Mediterranean areas (Molina et al., 2016). Regarding fire impacts, San-Miguel-Ayanz et al. (2012b) have estimated that approximately 80.000 ha of Natura 2000 sites have burned every year between 2000 and 2012, with Portugal and Spain being the most affected countries. Within the boundaries of this protected area in Minho region, the differences in wildfire vulnerability can be due to varying sensitivity levels related to differing fireproneness, fuel susceptibility to damages or resilience of existing vegetation communities (Proença et al., 2010). Around 36\% of Peneda-Gerês national park is occupied by shrubland, $20 \%$ is forest and $34 \%$ is covered with no fuels (corresponding to water or bare rocks). Aretano et al. (2015) also found differing sensitivity levels in a natural protected area depending on the susceptibility to damages of the vegetation or on the tourist vocation, and consequently higher human stressors, of the different land cover types.

The southwestern part of the region showed, in contrast, lower vulnerability to wildfires, due to the higher presence of urbanized areas. Also, the resources of firefighters in Portugal, as in other countries, are mostly concentrated in urban centers, where more people live (Fig. 4, C). Therefore, the coping capacity regarding firefighting resources is higher in urbanized areas than in rural ones (Brotons et al., 2013; Piñol et al., 2005) despite the larger prevalence of fuels in the latter.

The spatial patterns of exposure and sensitivity indices showed substantial differences (Fig. 4A and B). Sensitivity levels have a 


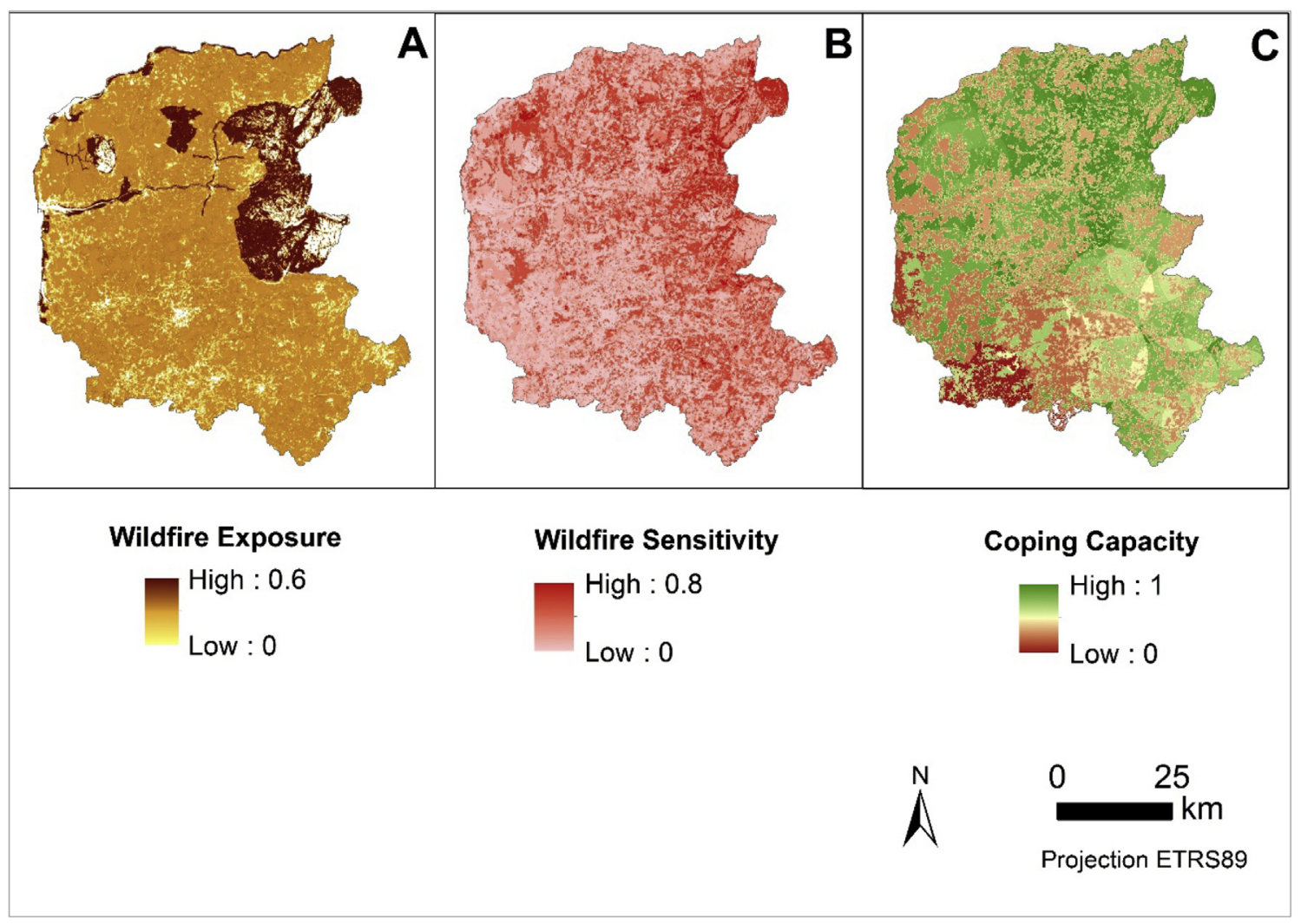

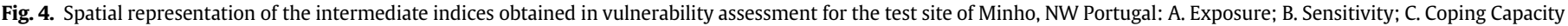
(reverse scale).

dispersed pattern, whereas exposure levels appear clustered. The exposure map represents, on one hand, the relative importance of each asset exposed and, on the other hand, the number of exposed assets present in each grid cell and the mutual exclusion of specific elements. For example, it is expected that natural protected areas have lower buildings density, or that areas with more population have a lower density of fuels.

Population sensitivity (Fig. 5, A) showed a heterogeneous pattern. The areas with lower population sensitivity largely coincide with the areas of higher fuel sensitivity (Fig. 5, B). Clusters of high population sensitivity are scattered inland, near the limits of the national park Peneda-Gerês. This trend is most likely associated with the socio-economic and demographic changes verified in the last decades in Portugal; rural and inland areas have suffered a substantial decline in population density, due to migration to coastal regions or other countries, mainly by younger people; therefore, population sensitivity reflects the ageing process of rural areas in Portugal (Moreira et al., 2011, 2001; Oliveira et al., 2017b).

The co-existence of population, buildings and infrastructures and wildland fuels, a strong pattern found in Minho region, brings specific challenges to fire managers, increasing exposure levels and hampering fire suppression activities (Chas-Amil et al., 2013; Herrero-Corral et al., 2012; Lampin-Maillet et al., 2011).

\subsubsection{SW Sardinia, Italy}

In the Italian test area, low wildfire vulnerability (class 1) was found in $42.8 \%$ of the area whilst high vulnerability levels (class 3 ) covered $29.6 \%$ of the area. Moderate levels (class 2) were found in $27.7 \%$ of the cells, high wildfire vulnerability (class 4 ) was scarcely represented and maximum level (class 5) was not found (Fig. 3). The lowest vulnerability levels are mainly concentrated in the NE part and the intermediate levels are spread through the NW and SE sides.

The spatial distribution of wildfire vulnerability seems to be closely related to fuel patterns, as previously found by other authors (Salis et al., 2013). Shrubland-type fuels cover over a third of the Italian site (36\%) and are found mainly in the northwest and southeast parts of the region. Non-wildland fuels, less fire-prone, occupy mostly the northeastern side.

Regarding population, it is evident a higher concentration of people and associated buildings in few urban centers within the territory (Fig. 6A, B and C), in opposition to the dispersed pattern found in Minho. In SW Sardinia, protected areas were less relevant than for Minho region, both in surface area and classification categories, although their influence was still seen in exposure levels.

\subsection{Validation}

i) Quality and reliability of the information

The exposure component was validated for 4921 and 3130 cells for Portugal and Italy, respectively. For test site 1 in Portugal, there was an overall match of $82 \%$ between the estimated classes and the observation of ground assets, whereas for the test area of Italy the correspondence was $72 \%$. For both areas, the proportion of positive match was lower for the moderate class $(67.9 \%$ and $66.8 \%$ for Portugal and Italy, respectively) and the accuracy was higher for class 1 (Low, $90.3 \%$ for Portugal site 1 and $76.1 \%$ for Italy site 2 ). For test site $1,72 \%$ of misclassified cells corresponded to overestimation, being classified by the model with a higher level than expected. For test site 2 , the proportion of overestimation was $43 \%$.

Fuel coverage and density presented the highest differences 


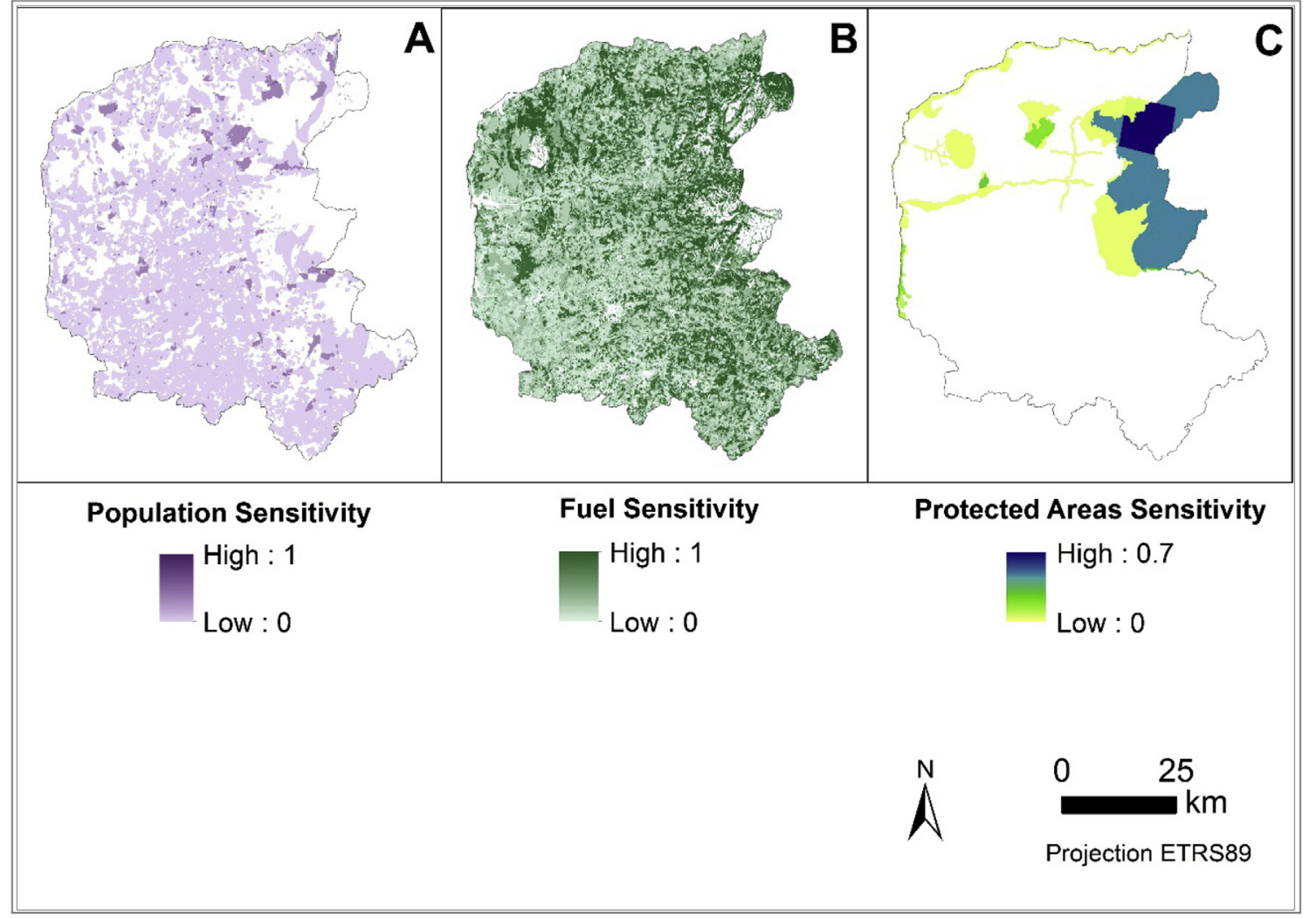

Fig. 5. Spatial representation of the variables included in sensitivity assessment for the test site of Minho, NW Portugal: A. Population; B. Fuels; C. Protected Areas.

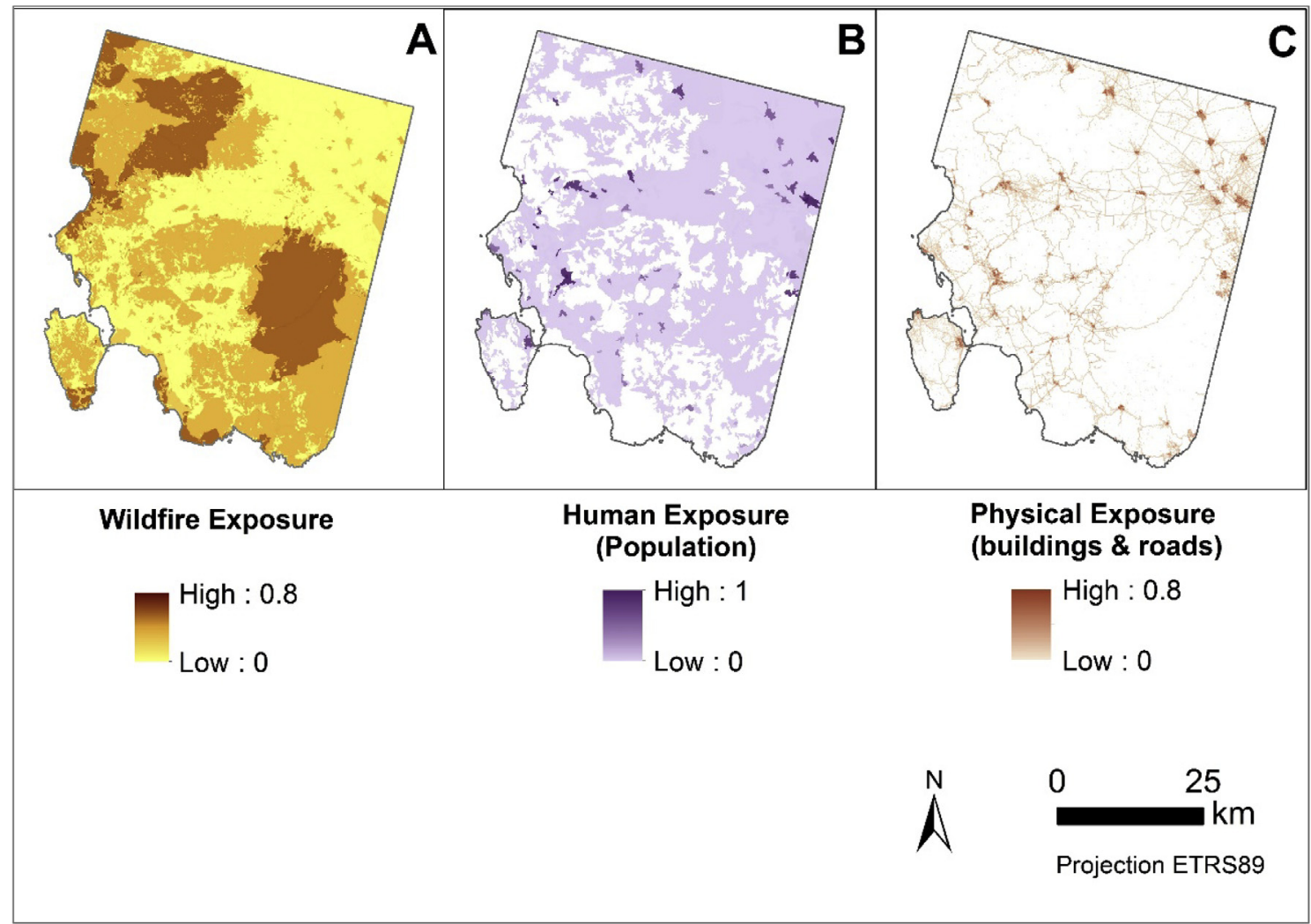

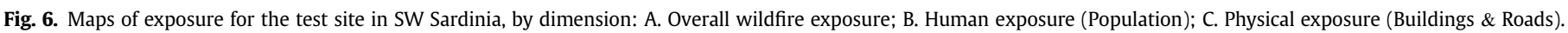


between estimated and observed classes. This can be associated with misinterpretation of specific fuel categories, from inaccuracies of the original fuel dataset or from the transformation of the data integrated in the model, issues that must be explored in further applications of this model. The main difference between the moderate and the high classes is the pertaining to a protected area, which increases exposure, assuming their high socio-economic and environmental value (Molina et al., 2016), higher susceptibility to damages and associated recovery costs.

All the cells classified by the model as high vulnerability (class 3 ) presented increased levels in the human dimension (above class 3), which shows the relevance of population variables in the model. Overall, the model showed a lower performance in estimating the higher classes of exposure and vulnerability levels.

ii) Consistency and replication of the vulnerability assessment procedure

The procedure developed was applied in NE Corsica, France (Fig. 1, site 3), following a request from stakeholders, and the exposure and sensitivity components were generated. The local users demonstrated a high level of confidence on the results, particularly for the exposure maps. Outputs could be provided in a timely manner, up to 3 days for ca. 300.000 cells at 1 ha resolution, given the input data is obtained in a suitable format and with modest technological capacity. Results showed that the lack of data, one of the challenges in holistic vulnerability assessment, does not preclude the application of specific steps of this procedure.

\subsection{Opportunities and challenges of the framework}

The access to spatial data for different regions and countries with the precision and accuracy required, becomes a significant barrier and adds uncertainty to the results, as it has been found by other authors (Aldersley et al., 2011; Birkmann et al., 2013; Chuvieco et al., 2014; Fekete et al., 2014; Gallina et al., 2016; Salis et al., 2013). The integration of variables that represent different realities at country and regional level required, as well, a strong consensus between participating users, not always easy to reach. This was partially overcome by implementing the framework as a stepwise procedure.

The application of a stepwise procedure allowed for the development of multiple outputs which can be tailored to the particular needs of different users. Previous research on vulnerability argued on the need to adapt the assessment framework to specific purposes (e.g., Ciurean et al., 2013; Costa and Kropp, 2013). Regarding wildfires, it is also expected that diverse landscapes will show different effects (Chuvieco et al., 2014; Koutsias et al., 2015; Moreira et al., 2011; Turco et al., 2016), thus an adjustable vulnerability framework is valuable.

The stepwise approach, and the creation of indices and maps along several steps of the processing chain, simplified the interpretation of results. In addition to the vulnerability map, the development of intermediate outputs allowed for a deeper understanding of the final outcome, since the spatial representation of each variable and component of the framework enabled a better perception of the characteristics of the assets and resources analyzed. Previous studies (Birkmann et al., 2013; Chuvieco et al., 2014; Kuhlicke et al., 2011), consider that the implementation of such procedure contributes to improve the systematic implementation of a holistic assessment of wildfire vulnerability, which is difficult to operationalize but required for applied research and for encouraging its use beyond the scientific domain. In fact, the improvement of fire management strategies requires from the science, which attempts to increase the understanding of systems and their multiple interactions, a simplified knowledge able to be transferred to the stakeholders, such as operational users, in order to develop pragmatic solutions to cope with specific threats (Costa and Kropp, 2013).

Despite the limitations on data availability and the fine-tuning required to ensure the applicability of the outputs in different areas and countries, the overall structure of the processing chain could be maintained. This option was possible due to the flexibility given by the stepwise procedure, as each step can be implemented separately and modified to some extent, without altering the overall framework arrangement. This flexibility extends to the input data, as additional or updated data can be integrated when it becomes available, while preserving the stability of the overall procedure, allowing for comparisons between regions and monitoring over time.

The assessment of the coping capacity component proved challenging. The activities and prevention measures vary among countries, as for example, the surveillance options with towers used in Portugal and paths by vehicle in France. It is likely that not all the required data exist for the different countries, nor that they will be directly available to researchers, thus the processing of this index may include a different number of variables in each area, implying an additional effort of data harmonization between countries.

\subsection{Implications for operational use and further application}

Following the results obtained and the feedback of the stakeholders, several recommendations were drawn for further improvement:

- The classification system implemented and the thresholds defined for vulnerability classes, as well as for the other components, can be refined to accommodate particular circumstances in different areas and to improve the representativeness of the resulting products with regards to local conditions;

- Additional data on seasonal population variation must be integrated in the framework when applied to areas where tourism is a major activity, as it is common in summertime in Greece or in southern Iberian peninsula;

- The clear definition of the Wildland-Urban Interface in the European Mediterranean region, considered a major concern in fire management activities, should be included in future applications of the framework when suitable data becomes available;

- The use of scientific research outputs at the operational level, although challenging, is facilitated by considering in the process the procedures already in place and the suggestions of potential end-users.

- In order to maintain the core characteristics of the framework, any adjustment implemented must be clearly defined and justified, to enable comparisons between areas and countries. Additional data can be integrated and may imply an adjustment to the weighting given to the variables, which should be tested and validated prior to any further application.

- The further use of the mapping tools provided by the framework for decision-making, may require aggregation at the administrative level, according to the practices implemented in each country.

\section{Conclusions}

Vulnerability assessment is of utmost importance in wildfire management and scientific research can provide valuable tools useful in other sectors. In this context, a holistic vulnerability assessment framework has been tested in several areas within 
Mediterranean Europe, taking into account specific requirements at the operational level from different regional and national stakeholders. This framework followed a stepwise procedure that allows for local or regional adjustments while maintaining consistent and comparable steps. Also, it provided a set of cartographic tools and different outputs besides the overall vulnerability map, such as exposure maps, environmental sensitivity or coping capacity evaluation, depending on users' needs and considering current institutional procedures. Therefore, the framework implemented has a strong relevance for fire managers and civil protection activities, contributing to define a systematic evaluation of wildfire vulnerability that can be easily translated into operational practices.

Some challenges remain regarding data availability, the difficulty in capturing certain dimensions through measurable variables and the incomplete analysis of coping capacity. As well, the validation of the outputs and the full implementation of the framework in context-specific areas require further research.

The application of efficient fire prevention and coping strategies depend on robust and consistent evaluations of damage potential. Vulnerability assessment should not be stalled by lack of data or rigid structures and, despite the challenges ahead, this approach encouraged the use of scientific research outputs allied with operational practices, implemented in different countries with common issues.

\section{Acknowledgments}

This work was developed under the framework of the PREFER project ("Space-based information support for Prevention and REcovery of forest Fire Emergency in MediteRranean areas"), financed by the European Community's Seventh Framework Programme ([FP7/2007-2013]) under G. A. nr. 312931. We would like to thank the anonymous reviewers, whose comments and suggestions have allowed us to improve this paper.

\section{Appendix A. Supplementary data}

Supplementary data related to this article can be found at https://doi.org/10.1016/j.jenvman.2017.10.003.

\section{References}

Ager, A.A., Day, M.A., McHugh, C.W., Short, K., Gilbertson-Day, J., Finney, M.A., Calkin, D.E., 2014. Wildfire exposure and fuel management on western US national forests. J. Environ. Manage. 145, 54-70. https://doi.org/10.1016/ j.jenvman.2014.05.035.

Alcasena, F.J., Salis, M., Ager, A.A., Arca, B., Molina, D., Spano, D., 2015. Assessing landscape scale wildfire exposure for highly valued resources in a mediterranean area. Environ. Manage. 55, 1200-1216. https://doi.org/10.1007/s00267015-0448-6.

Aldersley, A., Murray, S.J., Cornell, S.E., 2011. Global and regional analysis of climate and human drivers of wildfire. Sci. Total Environ. 409, 3472-3481. https:// doi.org/10.1016/j.scitotenv.2011.05.032.

Amatulli, G., Camia, A., San-Miguel-Ayanz, J., 2009. Projecting future burnt area in the EU-Mediterranean countries under IPCC SRES A2/B2 climate change scenarios. In: In Proceedings of the VII International EARSeL Workshop - Advances on Remote Sensing and GIS Applications in Forest Fire Management, No. JRC55149, pp. 33-38.

Amraoui, M., Liberato, M.L.R., Calado, T.J., DaCamara, C.C., Coelho, L.P., Trigo, R.M. Gouveia, C.M., 2013. Fire activity over mediterranean Europe based on information from Meteosat-8. For. Ecol. Manage. 294, 62-75. https://oi.org/ 10.1016/j.foreco.2012.08.032.

Aretano, R., Semeraro, T., Petrosillo, I., De Marco, A., Pasimeni, M.R., Zurlini, G., 2015. Mapping ecological vulnerability to fire for effective conservation management of natural protected areas. Ecol. Modell. 295, 163-175. https://doi.org/10.1016/ j.ecolmodel.2014.09.017.

Aubrecht, C., Özceylan, D., Steinnocher, K., Freire, S., 2013. Multi-level geospatial modeling of human exposure patterns and vulnerability indicators. Nat. Hazards 68, 147-163. https://doi.org/10.1007/s11069-012-0389-9.

Badia, A., Serra, P., Modugno, S., 2011. Identifying dynamics of fire ignition probabilities in two representative Mediterranean wildland-urban interface areas. Appl. Geogr. 31, 930-940. https://doi.org/10.1016/j.apgeog.2011.01.016.

Barros, A.M.G., Pereira, J.M.C., 2014. Wildfire selectivity for land cover type: does size matter? PLoS One 9, e84760. https://doi.org/10.1371/journal.pone.0084760. Birkmann, J., Cardona, O.D., Carreño, M.L., Barbat, A.H., Pelling, M., Schneiderbauer, S., Kienberger, S., Keiler, M., Alexander, D., Zeil, P., Welle, T., 2013. Framing vulnerability, risk and societal responses: the MOVE framework. Nat. Hazards 67, 193-211. https://doi.org/10.1007/s11069-013-0558-5.

Bowman, D.M.J.S., Balch, J.K., Artaxo, P., Bond, W.J., Cochrane, M.A., D'Antonio, C.M., Defries, R.S., Johnston, F.H., Keeley, J.E., Krawchuk, M.A., Kull, C.A., Mack, M., Moritz, M.A., Pyne, S.J., Roos, C.I., Scott, A.C., Sodhi, N.S., Swetnam, T.W., 2011. The human dimension of fire regimes on Earth. J. Biogeogr. 38, 2223-2236. https://doi.org/10.1111/j.1365-2699.2011.02595.x.

Brotons, L., Aquilué, N., de Cáceres, M., Fortin, M.-J., Fall, A., 2013. How fire history, fire suppression practices and climate change affect wildfire regimes in Mediterranean landscapes. PLoS One 8, e62392. https://doi.org/10.1371/ journal.pone.0062392.

Carmo, M., Moreira, F., Casimiro, P., Vaz, P., 2011. Land use and topography influences on wildfire occurrence in northern Portugal. Landsc. Urban Plan. 100, 169-176. https://doi.org/10.1016/j.landurbplan.2010.11.017.

Corona, P., Ascoli, D., Barbati, A., Bovio, G., Colangelo, G., Elia, M., Garfî, V., Iovino, F., Lafortezza, R., Leone, V., Lovreglio, R., Marchetti, M., Marchi, E., Menguzzato, G., Nocentini, S., Picchio, R., Portoghesi, L., Puletti, N., Sanesi, G., Chianucci, F., 2015. Integrated forest management to prevent wildfires under Mediterranean environments. Ann. Silvic. Res. 39, 1-22. https://doi.org/10.12899/asr-946.

Carvalho, A., Martins, H., Marques, C., Rocha, A., Borrego, C., Viegas, D.X., Miranda, A.I., 2011. Fire weather risk assessment under climate change using a dynamical downscaling approach. Environ. Model. Softw. 26, 1123-1133. https://doi.org/10.1016/j.envsoft.2011.03.012.

Chas-Amil, M.L., Touza, J., García-Martínez, E., 2013. Forest fires in the wildland-urban interface: a spatial analysis of forest fragmentation and human impacts. Appl. Geogr. 43,127-137. https://doi.org/10.1016/j.apgeog.2013.06.010.

Chuvieco, E., Aguado, I., Yebra, M., Nieto, H., Salas, P.J., Martín, M.P., Vilar, L., Martínez, J., Martín, S., Ibarra, P., Salas, J., Martín, M.P., Vilar, L., Martínez, J., Martín, S., Ibarra, P., De la Riva, J., Baeza, J., Rodríguez, F., Molina, J.R., Herrera, M.A., Zamora, R., 2010. Development of a framework for fire risk assessment using remote sensing and geographic information system technologies. Ecol. Modell. 221, 46-58. https://doi.org/10.1016/ j.ecolmodel.2008.11.017.

Chuvieco, E., Martínez, S., Román, M.V., Hantson, S., Pettinari, M.L., 2014. Integration of ecological and socio-economic factors to assess global vulnerability to wildfire. Glob. Ecol. Biogeogr. 23, 245-258. https://doi.org/10.1111/geb.12095.

Ciurean, R.L., Schröter, D., Glade, T., 2013. Conceptual frameworks of vulnerability assessments for natural disasters reduction. In: Approaches to Disaster Management - Examining the Implications of Hazards, Emergencies and Disasters. INTECH Open Access Publisher, pp. 3-32. https://doi.org/10.5772/55538.

Costa, L., Kropp, J.P., 2013. Linking components of vulnerability in theoretic frameworks and case studies. Sustain. Sci. 8, 1-9. https://doi.org/10.1007/ s11625-012-0158-4.

Cutter, S.L., Boruff, B.J., Shirley, W.L., 2003. Social vulnerability to environmental hazards. Soc. Sci. O. 84, 242-261. https://doi.org/10.1111/1540-6237.8402002.

Cutter, S.L., 2015. Pool knowledge to stem losses from disasters. Nature 522, 7-9. https://doi.org/10.1038/522277a.

Cutter, S.L., 2011. A ciência da vulnerabilidade: modelos, métodos e indicadores. Rev. Crit. Cienc. Sociais 93, 59-69.

Darques, R., 2015. Mediterranean cities under fire. A critical approach to the wildland-urban interface. Appl. Geogr 59, 10-21. https://doi.org/10.1016/ j.apgeog.2015.02.008.

Dudley, N., Stolton, S., 2008. In: Defining Protected Areas: an International Conference in Almeria, Spain, IUCN Protected Areas Categories Summit. IUCN, Gland, Switzerland.

Duguy, B., Alloza, J.A., Baeza, M.J., De la Riva, J., Echeverría, M., Ibarra, P., Llovet, J., Cabello, F.P., Rovira, P., Vallejo, R.V., 2012. Modelling the ecological vulnerability to forest fires in mediterranean ecosystems using geographic information technologies. Environ. Manage. 50, 1012-1026. https://doi.org/10.1007/s00267012-9933-3.

EC, 2015. Forest Fires in Europe, Middle East and North Africa 2014. European Commission. https://doi.org/10.2788/224527.

Fekete, A., Hufschmidt, G., Kruse, S., 2014. Benefits and challenges of resilience and vulnerability for disaster risk management. Int. J. Disaster Risk Sci. 5, 3-20. https://doi.org/10.1007/s13753-014-0008-3.

Fernandes, P.M., 2013. Fire-smart management of forest landscapes in the Mediterranean basin under global change. Landsc. Urban Plan. 110, 175-182. https:// doi.org/10.1016/j.landurbplan.2012.10.014.

Gaither, C.J., Poudyal, N.C., Goodrick, S., Bowker, J.M., Malone, S., Gan, J., 2011. Wildland fire risk and social vulnerability in the Southeastern United States: an exploratory spatial data analysis approach. For. Policy Econ. 13, 24-36. https:// doi.org/10.1016/j.forpol.2010.07.009.

Galiana-Martín, L., Karlsson, O., 2012. Development of a methodology for the assessment of vulnerability related to wildland fires using a multi-criteria evaluation. Geogr. Res. 50, 304-319. https://doi.org/10.1111/j.17455871.2011.00718.x.

Gallina, V., Torresan, S., Critto, A., Sperotto, A., Glade, T., Marcomini, A., 2016 A review of multi-risk methodologies for natural hazards: consequences and challenges for a climate change impact assessment. J. Environ. Manage. 168, 
123-132. https://doi.org/10.1016/j.jenvman.2015.11.011.

Ganteaume, A., Camia, A., Jappiot, M. San-Miguel-Ayanz, J., Long-Fournel, M. Lampin, C., 2013. A review of the main driving factors of forest fire ignition over Europe. Environ. Manage. 51, 651-662. https://doi.org/10.1007/s00267-0129961-z.

Geldmann, J., Barnes, M., Coad, L., Craigie, I.D., Hockings, M., Burgess, N.D., 2013. Effectiveness of terrestrial protected areas in reducing habitat loss and population declines. Biol. Conserv. 161, 230-238. https://doi.org/10.1016/ j.biocon.2013.02.018.

Giannakopoulos, C., Le Sager, P., Bindi, M., Moriondo, M., Kostopoulou, E., Goodess, C.M., 2009. Climatic changes and associated impacts in the Mediterranean resulting from a 2 C global warming. Glob. Planet. Change 68, 209-224.

Gomes, J.F.P., 2006. Forest fires in Portugal: how they happen and why they happen. Int. J. Environ. Stud. 63, 109-119. https://doi.org/10.1080/00207230500435304.

Herrero-Corral, G., Jappiot, M., Bouillon, C., Long-Fournel, M., 2012. Application of a geographical assessment method for the characterization of wildland-urban interfaces in the context of wildfire prevention: a case study in western Madrid. Appl. Geogr. 35, 60-70. https://doi.org/10.1016/j.apgeog.2012.05.005.

Ibarra, P., Alloza, J.A., Pérez-Cabello, F., De la Riva, J., Baeza, M.J., Echeverría, M.T., Llovet, J., Rovira, P., Vallejo, V.R., 2007. Ecological vulnerability to forest fires: an evaluation model. In: Wildfire2007. Sevilla, Spain, pp. 1-12.

Koutsias, N., Allgöwer, B., Kalabokidis, K., Mallinis, G., Balatsos, P., Goldammer, J.G., 2015. Fire occurrence zoning from local to global scale in the European Mediterranean basin: implications for multi-scale fire management and policy. iForest Biogeosciences For. 9, 195-204. https://doi.org/10.3832/ifor1513-008.

Kovats, R.S., Valentini, R., Bouwer, L.M., Georgopoulou, E., Jacob, D., Martin, E., Rounsevell, M. Soussana, J.-F., 2014. Europe. In: Barros, V.R., Field, C.B. Dokken, D.J., Mastrandre, M.D. (Eds.), Climate Change 2014: Impacts, Adaptation, and Vulnerability. Part B: Regional Aspects. Contribution of Working Group II to the Fifth Assessment Report of the Intergovernmental Panel on Climate Change. Cambridge University Press, Cambridge, United Kingdom and New York, NY, USA, pp. 1267-1326.

Kuhlicke, C., Scolobig, A., Tapsell, S., Steinführer, A., Marchi, B., 2011. Contextualizing social vulnerability: findings from case studies across Europe. Nat. Hazards 58, 789-810. https://doi.org/10.1007/s11069-011-9751-6.

Lampin-Maillet, C., Long-Fournel, M., Ganteaume, A., Jappiot, M., Ferrier, J.P., 2011. Land cover analysis in wildland-urban interfaces according to wildfire risk: a case study in the South of France. For. Ecol. Manage. 261, 2200-2213. https:// doi.org/10.1016/j.foreco.2010.11.022.

Laneve, G., Bonis, R. De, Fusilli, L., Ferrucci, F., Sebástian-Lopéz, A., Oliveira, S., Clandillon, S., Tampellini, L., Hirn, B., Diagourtas, D., Leventakis, G., 2014. PREFER FP7 project for the management of the pre- and post-fire phases: presentation of the products. In: Advances in Forest Fire Research, pp. 903-911.

Molina, J.R., y Silva, F.R., Herrera, M.Á., 2016. Integrating economic landscape valuation into Mediterranean territorial planning. Environ. Sci. Policy 56, 120-128. https://doi.org/10.1016/j.envsci.2015.11.010.

Moreira, F., Rego, F.C., Ferreira, P.G., 2001. Temporal (1958-1995) pattern of change in a cultural landscape of northwestern Portugal: implications for fire occurrence. Landsc. Ecol. 16, 557-567.

Moreira, F., Viedma, O., Arianoutsou, M., Curt, T., Koutsias, N., Rigolot, E., Barbati, A., Corona, P., Vaz, P., Xanthopoulos, G., Mouillot, F., Bilgili, E., 2011. Landscape-wildfire interactions in southern Europe: implications for landscape management. J. Environ. Manage. 92, 2389-2402. https://doi.org/10.1016/ j.jenvman.2011.06.028.

Moreno, J.M., 2009. Impacts on potential wildfire risk due to changes in climate. In: Living with Wildfires: what Science Can Tell Us. A Contribution to the Sciencepolicy Dialogue. EFI Discusión Paper.

Moriondo, M., Good, P., Durao, R., Bindi, M., Giannakopoulos, C., Corte-Real, J., 2006. Potential impact of climate change on fire risk in the Mediterranean area. Clim. Res. 31, 85-95.

Murthy, C.S., Laxman, B., Sesha Sai, M.V.R., 2015. Geospatial analysis of agricultural drought vulnerability using a composite index based on exposure, sensitivity and adaptive capacity. Int. J. Disaster Risk Reduct. 12, 1-9. https://doi.org/ 10.1016/j.ijdrr.2015.01.004.

Naughton-Treves, L., Holland, M.B., Brandon, K., 2005. The role of protected areas in conserving biodiversity and sustaining local livelihoods. Annu. Rev. Environ. $\begin{array}{llll}\text { Resour. } & 30, & 219-252 . & \text { https://doi.org/10.1146/ }\end{array}$ annurev.energy.30.050504.164507.

Ninan, K.N.N., Inoue, M., 2013. Valuing forest ecosystem services: what we know and what we don't. Ecol. Econ. 93, 137-149. https://doi.org/10.1016/ j.ecolecon.2013.05.005.

Nunes, A., Lourenço, L., Castro Meira, A.C., 2016. Exploring spatial patterns and drivers of forest fires in Portugal (1980-2014). Sci. Total Environ. 573, 1190-1202. https://doi.org/10.1016/j.scitotenv.2016.03.121.

Oliveira, S., Laneve, G., Fusilli, L., Eftychidis, G., Nunes, A., Lourenço, L., SebastiánLópez, A., 2017a. A common approach to foster prevention and recovery of forest fires in Mediterranean Europe. In: Mediterranean Identities - Environment, Society, Culture. INTECH Open Access Publisher. ISBN: 978-953-51-55034 (in press).

Oliveira, S., Moreira, F., Boca, R., San-Miguel-Ayanz, J., Pereira, J.M.C., 2014. Assessment of fire selectivity in relation to land cover and topography: a comparison between Southern European countries. Int. J. Wildl. Fire 23, 620-630.
Oliveira, S., Zêzere, J.L., Queirós, M., Pereira, J.M., 2017b. Assessing the social context of wildfire-affected areas. The case of mainland Portugal. Appl. Geogr. 88, 104-117. https://doi.org/10.1016/j.apgeog.2017.09.004.

Oppenheimer, M., Campos, M., Warren, R., Birkmann, J., Luber, G., O'Neill, B. Takahashi, K., 2014. Emergent risks and key vulnerabilities. In: Climate Change 2014: Impacts, Adaptation, and Vulnerability. Part A: Global and Sectoral Aspects. Contribution of Working Group II to the Fifth Assessment Report of the Intergovernmental Panel on Climate Change Climate Change 2014: Impacts, Adaptation, an. Cambridge University Press, Cambridge, United Kingdom and New York, NY, USA, pp. 1039-1099.

Ortega, M., Saura, S., González-Avila, S., Gómez-Sanz, V., Elena-Rosselló, R., 2012. Landscape vulnerability to wildfires at the forest-agriculture interface: halfcentury patterns in Spain assessed through the SISPARES monitoring framework. Agrofor. Syst. 85, 331-349. https://doi.org/10.1007/s10457-011-9423-2.

Pausas, J.G., Llovet, J., Rodrigo, A., Vallejo, R., 2008. Are wildfires a disaster in the Mediterranean basin? - A review. Int. J. Wildl. Fire 17, 713-723. https://doi.org/ 10.1071/WF07151.

Piñol, J., Beven, K., Viegas, D.X., 2005. Modelling the effect of fire-exclusion and prescribed fire on wildfire size in Mediterranean ecosystems. Ecol. Modell. 183, 397-409. https://doi.org/10.1016/j.ecolmodel.2004.09.001.

Proença, V., Pereira, H.M., Vicente, L., 2010. Resistance to wildfire and early regeneration in natural broadleaved forest and pine plantation. Acta Oecol. 36 626-633. https://doi.org/10.1016/j.actao.2010.09.008.

Raftoyannis, Y., Nocentini, S., Marchi, E., Sainz, R.C., Guemes, C.G., Pilas, I., Peric, S., Paulo, J.A., Moreira-Marcelino, A.C., Costa-Ferreira, M., Kakouris, E., Lindner, M. 2014. Perceptions of forest experts on climate change and fire management in European Mediterranean forests. iForest Biogeosci. For. 7, 33-41. https:// doi.org/10.3832/ifor0817-006.

Rego, F., 2004. Análise da cobertura da rede nacional de postos de vigia, Relatório final. CEABN/ADISA - INESC Inovação. Dezembro 2004.

Roberts, N., Meadows, M.E., Dodson, J.R., 2001. The history of mediterranean-type environments: climate, culture and landscape. Holocene 11, 631-634. https:// doi.org/10.1191/09596830195663.

Rodrigues, M., San Miguel, J., Oliveira, S., Moreira, F., Camia, A., 2013. An insight into spatial-temporal trends of fire ignitions and burned areas in the European mediterranean countries. J. Earth Sci. Eng. 3, 497-505.

Rodríguez, F., Ramón, J., Martínez, M., Soto, M.C., 2013. Methodological Approach for Assessing the Economic Impact of Forest Fires Using MODIS Remote Sensing Images.

Román, M.V., Azqueta, D., Rodrígues, M., 2013. Methodological approach to assess the socio-economic vulnerability to wildfires in Spain. For. Ecol. Manage. 294 158-165. https://doi.org/10.1016/j.foreco.2012.07.001.

Ruiz-Mirazo, J., Martínez-Fernández, J., Vega-García, C., 2012. Pastoral wildfires in the Mediterranean: understanding their linkages to land cover patterns in managed landscapes. J. Environ. Manage. 98, 43-50. https://doi.org/10.1016/ j.jenvman.2011.12.017.

Salis, M., Ager, A.A., Alcasena, F.J., Arca, B., Finney, M.A., Pellizzaro, G., Spano, D. 2015. Analyzing seasonal patterns of wildfire exposure factors in Sardinia, Italy. Environ. Monit. Assess. 187, 1-20. https://doi.org/10.1007/s10661-014-4175-x.

Salis, M., Ager, A.A., Arca, B., Finney, M.A., Bacciu, V., Duce, P., Spano, D., 2013. Assessing exposure of human and ecological values to wildfire in Sardinia, Italy. Int. J. Wildl. Fire 22, 549-565. https://doi.org/10.1071/WF11060.

San-Miguel-Ayanz, J., Durrant, T., Boca, R., Camia, A., 2012b. Forest Fire Damage in Natura 2000 Sites 2000-2012 (techreport). JRC scientific and policy reports. https://doi.org/10.2788/77848.

San-Miguel-Ayanz, J., Moreno, J.M., Camia, A., 2013. Analysis of large fires in European Mediterranean landscapes: lessons learned and perspectives. For. Ecol. Manage. 294, 11-22. https://doi.org/10.1016/j.foreco.2012.10.050.

San-Miguel-Ayanz, J., Rodrigues, M., Oliveira, S.S., Pacheco, C.K., Moreira, F. Duguy, B., Camia, A., 2012a. Land cover change and fire regime in the European mediterranean region. In: Moreira, F., Arianoutsou, M., Corona, P., De las Heras, J. (Eds.), Post-fire Management and Restoration of Southern European Forests. Springer Netherlands, Dordrecht, pp. 21-43.

Tapsell, S., Mccarthy, S., Faulkner, H., Alexander, M., Kuhlicke, C., Brown, S. Walker, G., Scolobig, A., De Marchi, B., Bianchizza, C., 2010. Social Vulnerability to Natural Hazards. CapHaz-Net - WP4 Report. London.

Taubenböck, H., Post, J., Roth, A., Zosseder, K., Strunz, G., Dech, S., 2008. A conceptual vulnerability and risk framework as outline to identify capabilities of remote sensing. Nat. Hazards Earth Syst. Sci. 8, 409-420. https://doi.org/10.5194/nhess8-409-2008.

Tedim, F., Remelgado, R., Borges, C., Carvalho, S., Martins, J., 2013. Exploring the occurrence of mega-fires in Portugal. For. Ecol. Manage. 294, 86-96. https:// doi.org/10.1016/j.foreco.2012.07.031.

Thompson, M.P., Haas, J.R., Gilbertson-Day, J.W., Scott, J.H., Langowski, P., Bowne, E., Calkin, D.E., 2015. Development and application of a geospatial wildfire exposure and risk calculation tool. Environ. Model. Softw. 63, 61-72. https://doi.org/ 10.1016/j.envsoft.2014.09.018.

Thompson, M.P., Scott, J., Kaiden, J.D., Gilbertson-Day, J.W., 2013. A polygon-based modeling approach to assess exposure of resources and assets to wildfire. Nat Hazards 67, 627-644. https://doi.org/10.1007/s11069-013-0593-2.

Turco, M., Bedia, J., Di Liberto, F., Fiorucci, P., von Hardenberg, J., Koutsias, N., Llasat, M.-C., Xystrakis, F., Provenzale, A., 2016. Decreasing fires in 
mediterranean Europe. PLoS One 11, e0150663. https://doi.org/10.1371/ journal.pone.0150663.

Turner, B.L., Kasperson, R.E., Matson, P.A., McCarthy, J.J., Corell, R.W., Christensen, L., Eckley, N., Kasperson, J.X., Luers, A., Martello, M.L., Polsky, C., Pulsipher, A., Schiller, A., 2003. A framework for vulnerability analysis in sustainability science. Proc. Natl. Acad. Sci. U. S. A. 100, 8074-8079. https://doi.org/10.1073 pnas.1231335100.

UNISDR, 2015. Sendai Framework for Disaster Risk Reduction 2015-2030 (Report).
UNISDR, 2009. Terminology on Disaster Risk Reduction. United Nations International Strategy for Disaster Reduction (UNISDR). https://dx.doi.org/978-6006937-11-3.

Urbieta, I.R., Zavala, G., Bedia, J., Gutiérrez, J.M., San Miguel-Ayanz, J., Camia, A., Keeley, J.E., Moreno, J.M., 2015. Fire activity as a function of fire-weather seasonal severity and antecedent climate across spatial scales in southern Europe and Pacific western USA. Environ. Res. Lett. 10, 114013. https://doi.org/10.1088/ 1748-9326/10/11/114013. 